\title{
Park of Forged Figures as an Art Practice of Ukrainian Blacksmithing
}

\author{
SVITLANA ROHOTCHENKO \\ postgraduate student, Modern Art Research Institute of the National Academy of Arts of Ukraine \\ orcid.org/0000-0002-6353-8591
}

\begin{abstract}
The Park of Forged Figures in Donetsk is a unique artistic, sociocultural, and political phenomenon. There is no other such exhibition space for contemporary blacksmithing art neither in Ukraine nor abroad. This creative and subsequently museum space was set up by the blacksmithing community of Ukraine; its size and number of works on display makes it probably the largest in Ukraine up to date.

During the period of 2001-2013, the Park of Forged Figures was a place for the annual gatherings for the blacksmiths from all regions of Ukraine and from abroad. This outstanding platform included blacksmithing workshops, specialized conferences, as well as informal meetings focusing on professional experiments in this field of creative art. Along with the annual Blacksmiths Festival in Ivano-Frankivsk, the Park of Forged Figures in Donetsk during the mentioned period became an unparalleled site for creative experiments and practicing blacksmithing craft, for expressive innovations and stylistic diversity. Thus, the relevance of the research is based on the conceptual load of the Park's projects that needs to be studied; also the landmark role of the Park in the social-cultural advance of the country should be outlined.

Keywords: blacksmithing, the Park of Forged Figures, decorative metalwork, polystilism, festival
\end{abstract}

Problem statement. The relevance of the study is in painting a broad and comprehensive picture of genres and styles used by the contemporary Ukrainian blacksmiths whose works were exhibited in the Park of Forged Figures. Additional aim would be defining strategic and educational role of the Park in the discourse of the contemporary culture of Ukraine.

Analysis of recent research works and publications. Despite the lack of comprehensive academic publications covering the revival and development of Ukrainian blacksmithing art, a number of Ukrainian and foreign researchers in the field still should be mentioned. The genre and stylistic trends, technologies, and history of development of blacksmithing art were partially covered in the research works by S. Bonkovska [2], L. Borschenko [3], G. Volodin [6], P. Zholtovkyi [7], V. Kotsarenko [10], I. Loshadkin [12], V. Mohylevskyi [13], I. Popiuk [15], I. Rudenko, [19], and R. Shmahalo [21].
The research work by V. Mohylevskyi [13] and I. Rudenko [19] stand out, as they present not only practical aspects of blacksmithing craft but also culture generating role of blacksmithing practices as trademark features of the cultural identity of Ukraine.

Aim of the article is to analyze the role of the Park of Forged Figures as an exhibition space combining various style, genre, and technological trends of Ukrainian and global blacksmithing.

The objectives are the following:

- to study the stylistic features of certain artworks in the Park of Forged Figures,

- to provide a comprehensive characteristic of the corporate co-creation in the Park's projects,

- to define the role of blacksmithing artworks in organizing the space of the Park,

- to highlight the culture-generating potential of this phenomenon. 
Presentation of the main research material. In the present time, the scale of progress in metal works is enormous. The masters who worked in the heyday of blacksmithing in the end of the $19^{\text {th }}$ and in the early $20^{\text {th }}$ century could not have dreamed of the technologies available to contemporary blacksmith. Nevertheless, the blacksmithing spirit and manual work remain the stable categories in the blacksmithing up to the present day, even when computer and laser technologies are used. Blacksmithing has been and remains an artistic profession where the flow of time as if slows down and sometimes virtually stops at all. The cuttingedge technologies of metal work often are abandoned while manually crafting the works of art. For millennia, furnace, hand-held hammer, and chisel remain irreplaceable. The machine did not manage to become an acceptable substitute to preform decorative ironwork with.

During the turn of the $21^{\text {st }}$ century, the first conflicts in decorative ironwork emerged. Despite the fact that there existed an extensive production network offering equipment for creating blacksmithing pieces, almost perfectly identically replicated, despite job cuts at the production sites, and, most importantly, significant reduction of the production cost, the blacksmithing community initiated the active revival of traditional blacksmithing craft based on turning back to the technological practices of the past.

Artists-blacksmiths persistently brought old craft secrets and lost technologies back to life, developing new styles in Ukrainian blacksmithing. These processes were almost identical in all the regions of the country. As a result, the First Creative Festival was held in the city of Donetsk.

The start of the new millennium was marked with the founding of the unique part of metalwork objects that later entered the pages of Ukrainian art history as the Park of Forged Figures. The revival of Ukrainian blacksmithing during the second half of the 1990s was also influenced by the blacksmithing festivals and operation of Donetsk-based Gefest enterprise and its leader and founder Victor Burduk, whose role in the overall revival process is unquestionable.
From the geopolitical point of view, such Park should have emerged in Donetsk - an administrative center of the Donetsk Oblast-specifically. The coat of arms of the Donetsk Oblast received the official approval of the Session of the Regional Council on August 17, 1999. "It depicts is the azure Mertsalov palm tree upon the golden shield with a black bent in base. On the top of the coat of arms there is a golden crown with five narrowing bands framed with a green wreath of oak leaves. The Motto states: 'The possibility proven by a deed.' This palm tree is forged of steel by O. Mertsalov, a blacksmith, in 1896" [20]. "The possibility proven by a deed" is both a motto of the Donetsk Oblast and a slogan from the Mertsalov palm tree metalwork. Oleksiy Mertsalov was an outstanding blacksmith who worked at the Yuzivka factory at the turn of the $20^{\text {th }}$ century. The Donetsk region has always been multi-national for centuries, as the people who settled there had various professions and spoke different languages. The risks of working under ground in the mines eventually united people who became the driving force for development of industry in the region and, subsequently, for founding the Park of Forged Figures. Clearly, on the eve of the $21^{\text {st }}$ century blacksmithing was on the rise. Victor Burduk, the Honored Worker of Arts of Ukraine, played a much appreciated role in the process, however, he did not initiate it all by himself.

Entire blacksmithing community of Ukraine, and later on-of close and distant neighbors, also answered the call to join forces in founding and developing the Park of Forged Figures. During the period between 2001 and 2011 there were over 200 unique manually crafted artworks added to the Park, produced both by individual artists-blacksmiths and blacksmithing enterprises from all over Ukraine. At the present time, the Park has over 300 artworks. The Park as if repeats the overall history of the region that was founded and made famous by the people from all around the country.

The Park not only organized the space of the city square but also became one of the bricks in the foundation of future Union of Blacksmiths of Ukraine and in the solid development of Ukrainian black- 
smithing art. Yevhen Yaseniv, a Donetsk-based writer and journalist, in his book A Tour of Donetsk describes the site where the Park was founded. "Before 2001, the square between the building of the Municipal Executive Committee and Universytetska street did not really catch the imagination. This was a nofrills city square, even the benches were almost all gone. Certainly, it was well-kept (it was a city center, after all, right by the 'White House'), but that was it, enough for the mayor's peace of mind. And then it all changed thanks to Oleksiy Mertsalov and Victor Burduk" [22, p. 87].

The Park of Forged Figures, a unique open-air exhibition space, was founded in 2001. That year, the first 10 figures were installed. A year after there were 19 more figures added. Now, there are over 300 different-themed artworks in the Park. The youngest visitors are most interested in the Fairy Tales Alley, and those fond of astrology would love the Signs of Zodiac alley. The Park also has the Alley of Favorite City, the Alley of Masters, the Architectural Copies Alley. The namesake festival was held yearly, starting in 2001. Victor Burduk described the event in the following way, "The theme of the festival is changed yearly and everyone who considers himself to be a master in blacksmithing craft, can bring his artwork and become a participant. The best work, at author's will, are presented as a gift to the city of Donetsk and are installed in the Park permanently. The city dwellers and tourists not only have a chance to enjoy the masters' work but also to attend workshops right there in the park. The festival includes competitions: blacksmith's cooking, blacksmith's costume, and a strongmen contest. Traditional music festival Rock Forge marks the finish of the overall event. Donetsk is the land where blacksmithing was first revived in Ukraine; it was also the first city from the former USSR to join The Ring of the European Cities of Iron Works, an international blacksmithing organization. The Park of Forged Figures is a monument to all blacksmithing masters both in Donetsk and in Ukraine in general" [8].

Some artworks in the Park should be described in detail. The first ten works were authored by the mas- ters from Donetsk. It all started with The Rose of Do$n e t s k$, a collective piece, produced by the Gefest enterprise and presented to the city. The intrigue was simple. Donetsk is the city of million roses, beautiful live flowers, in blossom all summer. The metal rose was supposed to symbolize eternity of the famed city. Other artworks were Oblivion by Ye. Yermak, La-lafa by P. Sarzhan, Speed by V. Burduk and Yu. Tykhanov, Stork by O. Sukharev and O. Hurov, Rosy Future by S. Kaspruk, Flower Garden and Burionush$k a$ by V. Kovalenko, Cat by V. Ternovyi and P. Malochynskyi, Butterfly by D. Sytdytkov and V. Ternovyi, Firebird by V. Burduk and S. Prudnikov, Weather Vane by V. Burduk and N. Hrymailo. Eleven original artworks at first seemed to be "lost" in the Park. Yet, eventually they started the unique socio-cultural project that would not only immortalize Donetsk, a miners' capital, but also, along with Ivano-Frankivsk blacksmithing festival Ornamental Blacksmithing, pave the path for Ukrainian blacksmithing art.

The following year, 2002, there were 26 sculptures in the Park. New artists-blacksmiths contributed. P. Malochynskyi completes Horse, a tricky artwork. And S. Kozyk contributes with his composition Model with the Weather Vane. In 2003, the Dragon Gazebo was installed in the Park, as well as The Tree of Life gazebo that would make Donetsk famous at the Millennium World Exhibition in Hanover in 2000. The original artwork The Tree of Life by Victor Burduk was presented by the author to the fellow devotee of blacksmithing who contributed to reviving the blacksmithing traditions of Europe and founded a blacksmithing school of his own-to celebrated Dutchman Huub Sensen. The copy of The Tree of Life, also performed by an author, stands in Donetsk up to this day. The Dutch artist-blacksmith Huub Sensen, a world's leading expert in the field, liked the piece for a reason. On the one hand, the artwork incorporates many references to the traditional old Ukrainian techniques of metalwork; on the other hand-it includes modern technologies. This composition was a new solution in Ukrainian and global blacksmithing, when contemporary and traditional technologies were merged. 
The Tree of Life forged gazebo has many details, numbering several thousands. They were attached not with the traditional method of hot forging, when details are heated up to thousand degrees, until they turn red, and then hammered or riveted with the special rivets used in the old times. Instead, the parts were joined together with the dot welding. To replicate the bark of a tree, special instruments were sharpened; with these little hammers, blacksmiths chiseled every millimeter of the trunk and branches. This technology was used in chased work on the soft metals, like copper and aluminum. The masters from Donetsk were the first to use this technology in order to visually depict bark on a hard steel plane. The fence around the tree also looked quite realistic and echoed the wooden hedges that were once typical for Ukrainian countryside. The rhythm of "wooden" planks resembled a real-life fence. Sunflowers and periwinkletraditional elements of the rural Ukrainian landscapewere skillfully forged and painted with special paint that accurately conveyed the color of live sunflower. Iron jars, hung on the tops of the planks for drying, were the exact copies of the jars that actually had hung in the rural fences in the previous centuries. The fantasy of Ukrainian artists-blacksmiths made cocks tree times larger than the real rooster sitting on the fence. The blacksmith included a lot of Ukrainian folk images in his artwork. Namely, the tree "symbolizes immortality, eternity of Life, its diversity. Live prevails over time, uniting the past, the present day, future, and space. It is the center of the world, it incorporates all planes of Existence" [16].

Wooden fence is like a talisman, a protection shield, border between "ours" and "alien." Valeriy Voytovych in his book Ukrainian Mythology states that, "The fence serves as a warding for the house, it stops unwanted guests, thus, it has a power to turn away" [5, p. 346]. Sunflower is a symbol of the Sun, of well-being and strength. V. Lototska notes that, "sunflower as the symbol of fertility and prosperity, of the energy of the sun and health, was particularly cherished in Ukrainian culture. For Ukrainians, this flower is one of the images of their Motherland; probably, that it why it could be seen even on the coats of arms of some
Ukrainian localities" [11, p. 1426]. The cock, who as if signals about the sunrise, symbolizes the family hearth. A. Afanasiev considers a cock to "represent the fire of a thunderstorm" and to be "a symbol of fire" [1, p. 127]. A clay jar is "a symbol of unity of the Earth and the Sun, without which the household fails to prosper. It is made of clay, which comes from the Earth, and burnt on fire, which comes from the Sun. A clay pot used for cooking food on the family hearth also sustains well-being of a house. Therefore, clay jar is perceived as a vessel for the spirit of the house and for the spirits of the predecessors-of the entire family and of the spirit of each of its members" [17].

The Tree of Life by Victor Burduk is a reflection of ethnic and national worldview that operates symbolical images formed in the process of interaction of the artist's perception of the world and cultural and natural environment. From the point of view of foreign professionals and blacksmithing lovers, The Tree of Life was a vivid example of ethnic culture and extremely skillfully crafted blacksmithing piece.

2004 was a hard year for Ukraine geopolitically. Nevertheless, the Donetsk blacksmithing festival was carried out and gathered a large number of participants from different regions of Ukraine. The Park of Forged Figures had a new landmark exhibit-Lovers' Gazebo that started a new page in the Park's history. The framework of the gazebo was jointly produced by several blacksmithing enterprises of Donetsk; it was decorated with the bouquets of forged flowers. The latter were brought to Donetsk by the blacksmiths from the various cities of Ukraine. This fact was not highly publicized, yet it became clear that blacksmithing masters would not fight over politics. Eventually, it also marked a start of joint work of artists-blacksmiths from all over Ukraine on the artwork that would sculpt the Park's space and would become a favorite spot for all Donetsk newlyweds to take their wedding photo shoots.

In 2005, the organizing committee of the festival set a new ambitious task- to craft the Zodiac signs. Participants from all over Ukraine had to perform an original Zodiac-themed composition. That is how the Alley of Zodiac Signs emerged in the park. This fact had 
both artistic and political implications. Blacksmiths from Donetsk region (Gefest, Opal, Prolisok enterprises) and from Ivano-Frankivsk, Kyiv, and Oleksandriya all participated in working on the Alley. 12 forged compositions organized the new space of the park that was from now on united with a common theme. Because of the individual styles of the artists-blacksmiths, each composition is unique.

The further development of the Park defined new prospects in regard to the coice of the themes. The organization committee took into consideration the viewers' requests. Thus, the next year, 2006, the theme of the festival were the heroes of the fairy tales. The new task urged the artists-blacksmiths to deeply feel these personages. Consequently, the features of the produced artworks were marked not only with individual style traits but also with the authors' visions of the folk heroes which were recreated in contemporary Ukrainian cultural field. Yevhen Yaseniv mentions that, "in 2006, 12 new forged personages of the fairy tales were added to the Park, namely, Kolobok, Thumbelina, Samodelkin, Wood Spirit, Svyatogor's Head, Tin Man, Pike, Genie, Buzzy-Wuzzy Busy Fly, Sir Cat-o-Puss, Pinoccio. Young mothers and grandmothers love to come there with their children and grandchildren to illustrate the daily read fairy tales with the real, though forged, figures" [10].

In May 2006, a unique forged Bouquet of Masters (performed by the blacksmiths at the Ivano-Frankivsk international blacksmithing festival) also "sprouted" in Donetsk. This was a joint work by 200 blacksmiths from 17 states. An opening ceremony for the forged sculpture Bouquet of Masters was held at the $8^{\text {th }}$ International Blacksmithing Festival in Donetsk. Original 5-meter vertical composition, assembled from the separate artworks of different artists, was meant to symbolize unity of the blacksmithing professionals and eventually became the compositional center of the space of the Park.

In 2007, the Park of Forged Figures significantly expanded. In the framework of the namesake festival, there was a new space founded within the park in 2007-the Alley of Arcs. The new alley had 11 forged figures made by the blacksmithing masters from seven regions of Ukraine. First-time contributors were Lutsk and Simferopol. 2007 was a special year for the forum in regard to the number of participating masters. Officially, 150 blacksmiths from 10 stated registered via the Festival's web-site. The theme for the blacksmithing event was an arch. The idea was to create the alley of arcs, with each highlighting some artistic features of blacksmithing art. The first to be installed was the Arc of Friendship that was decorated with creative forged pieces, jointly crafted by the blacksmiths right there at the festival. The line "made in" stated "Donetsk-Europe." The Alley of Arcs organized the space of the central alley of the park. The arcs, created by the festival's participants, are examples of monumental blacksmithing art. While being the large-scale pieces, they tower as high as 4-6 meters and reach up to 5 meters in width. Each of the artworks had its distinctive style features. The arc presented by the Rosych blacksmithing enterprise (Rokytne village, Kyiv Oblast) and the arc by Svarozhychi LLC (Oleksandriya, Kirovohrad Oblast) have visible modernism stylistic tendencies. The arc by Serhiy Tiasko from Uzhhorod is dominated by hi-tech style. A number of arcs represent the authors' experiments with floral and geometrical ornaments. Such are the one by the Romashenko private enterprise from Simferopol and by the Ptakh blacksmithing enterprise from Dnipropetrovsk. The fantastic beasts in the arc by the Kryshtaleva Kupel enterprise from Chernivtsi, and well as seemingly weightless arch full of butterflies made by Gefest enterprise from Donetsk, immediately capture viewers' attention.

In 2007, 16 unique objects were installed at the Alley: Benches for the Sweethearts by A. Chepyrdak (Ladyzhyn, Vinnytsia Oblast), A. Poturynskyi (Lubny, Poltava Oblast), L. Krasytskyi (Kramatorsk, Donetsk Oblast), A. Bondarenko (Kostiantynivka, Donetsk Oblast); the bench, crafted by the Ptakh studio-enterprise from Dnipropetrovsk, bench by D. Lystopad from Simferopol, and the bench by the creative duo of V. Soldatov and M. Vasyliev (Makiivka, Donetsk Oblast). The benched by I. Pukhyr (Berdiansk, Zaporizhzhia Oblast), by Viacheslav and Dmutro Vovchuk from Kharkiv, by V. Grynyshyn from the village of Vis- 
tria (Ternopil Oblast), by Korch blacksmithing studio from Ulianovsk (Russia), by Prolisok private enterprise from Donetsk, by V. Komonko from Koslov village in Ternopil Oblast, by Kovalska Manufaktura from Donetsk, and by Stefanova Kuznia from Kherson-all fascinated the viewers. The benches, aside from their utilitarian function, are also the works of art. In their production, such technologies as casting and forging were used. Some artworks had additional glass, wooden decorations, and lanterns. The style of the bench by V. Soldatov and M. Vasyliev (Makiivka, Donetsk Oblast) was clearly marked with modernism.

Thousands of the city dwellers of Donetsk and surrounding mining towns attended the festival in 2007. People from different regions of Ukraine and foreigners were sitting together by the long blacksmithing table, singing the songs and shared the meal of a traditional blacksmithing kulish. The 12ve International Blacksmithing Festival in the Park of Forged Figures commemorated then-mayor of Donetsk Oleksandr Lukianchenko as the honorary blacksmith; for many years he actively supported revival and development of Ukrainian blacksmithing art in the Eastern region.

The Ring of the European Cities of Iron Works acknowledged the contribution of Donetsk to development and promotion of blacksmithing art. In 2008, the Park of Forged Figures was declared to be a unique phenomenon in Europe, and Donetsk became a member city of the Ring of the European Cities of Iron Works. This took place at the general assembly of the organization that unites the blacksmithing masters from a number of European states. Thus, it makes sense that the creative theme for the 2008 was the Alley of Rings. By the start of the festival, eleven of them had arrived in Donetsk. The main "homework" exhibit was the European Ring, produced by Gefest enterprise in Donetsk. The piece was four meters in diameter. A footbridge went through the black metal ring, where silver inscription in English said "The Ring of the European Cities of Iron Works". The task for joint work was to decorate the Bridge of Friendship. Participating blacksmiths worked on decorative elements during the course of the festival. Each element was marked with unique indi- vidual style that turned the bridge into a polystylistic object. The bridge symbolized Ukraine's path to Europe and illustrated unity of the blacksmiths from around the world. The number of participants grew. The "homework" pieces, brought to the festival, show several style tendencies. For instance, the team of S. Tiasko, I. Aleksyk, and Ya. Potrohosh demonstrate their love for the hi-tech style. Kuznia Rosych blacksmithing enterprise (Rokytne village, Kyiv Oblast), D. Lystopad from Simferopol, Artferrum enterprise from Odesa, and Yu. Krush from Kyiv are of modernism style. Creative experiments of other participants are also interesting, especially when floral, geometrical ornaments, and other stylizations are used. The well-known participating blacksmiths were joined by the new emerging talents: I. Aleksyk, Yan Potrohosh and S. Tiasko from Uzhhorod, Yu. Krush from Kyiv, O. Hrytsiuk and V. Kamets from Lutsk. The participants liked the theme of benches and six more pieces were added to the Park in 2008. Geographically, the festival became even more diverse. Laguna from Chernivtsi, Tantiema enterprise from Kyiv, Dzherelo private enterprise from Lutsk, Zodchoy LLC from Kharkiv, A. Horobiuk from Rivne and V. Bezbakh from Odesa Oblast joined the participants of the previous years. Masterly performed pieces took their rightful place in the Park. Donetsk dwellers loved the benches straight off.

In 2009 , the Donetsk city $140^{\text {th }}$ founding anniversary defined the theme for the next Park of Forged Figures Festival. 140 years of mining history had to be properly commemorated. The Alley for the Beloved City was opened for the anniversary. The 5-meter bouquet of forged roses was the main gift. In was installed at the main street of the city. This blacksmithing gift from the blacksmithing community of the world included forged miniatures by the blacksmiths from several regions of Ukraine and from dozens of other states. Blacksmiths from Japan and Canada first participated in such a unique happening. Famed Huub Sensen from the Netherlands sent his artwork.

The themes for the festivals in the subsequent years were conditioned by life of the society. In 2010, during the 12ve Blacksmithing Festival, the Alley of Masters 
was opened, which was dedicated to the upcoming Euro 2012. Merry-go-round became the favorite site of the visitors. This exceptional artwork was crafted by the blacksmiths from Ivano-Frankivsk. In 2011, the Park celebrated its $10^{\text {th }}$ founding anniversary. The next year, 2012, a copy of the Eiffel tower (100 times smaller than the original) was added to the Park. Yet, three meters is high enough for a blacksmithing piece. This started the next page in the history of the Park-the Architectural Copies Alley.

Unfortunately, 2013 was the last year for the blacksmithing festival, already established at the international scene. However, blacksmithing festivals as an element of cultural space of the country still are traditional for the revived blacksmithing of the independent Ukraine. Blacksmithing festival has its distinctive features. Working a hard labor job, professional blacksmith come together to demonstrate their creative potential, to participate in specific professional contests, and, of course, to share a traditional dinner that united people of different faiths, traditions, artistic and political affiliations. The largest and most influential metal forums of Ukraine-held in Ivano-Frankivsk and in Donetsk-paved the path for the smaller festivals. Though attracting less visitors and participants, the latter are also essential for socio-cultural development.

The Donetsk festival illustrated the features of established regional blacksmithing schools and techniques. On this regard, Oleksa Yurchenko, a Kyivite, founder and general manager of the Tantiema (one of the largest blacksmithing enterprises in Ukraine), who repeatedly participated in blacksmithing festivals held at the Park of Forged Figures, states that, "Blacksmithing of Kyiv region, despite having a number of traits similar to blacksmithing of the Western and Eastern regions, is fundamentally different. This first came to my mind when I was observing the creative works in the general exposition of the Park of Forged Figures in 2008." Oleksa Yurchenko, an industrialist, mentions, "Meeting other blacksmiths in Donetsk, seeing other blacksmiths, schools, tendencies dramatically changed my attitude to the artistic component of a blacksmithing piece. I real- ized that it can be a work of art. This simple truth always was somewhere near, and yet me and my colleagues could make this discovery only while observing the large number of works on display. Clearly, we had participated in other exhibitions, but they were predominantly industrial ones. And the forum in Donetsk was an exhibition of creativity, of art. At first, I evaluated the works of others, paying more attention to the technical side of the piece: if the welding marks were removed, if there were scratches from an angle grinder, how the detail were pieced, if the size of the rod was adequate for the structure. Certainly, all of the above is important and right, but still, in my next visits to Ivano-Frankivsk festival, to Rivne Festival, and of course, to the Park of Forged Figures, I started to pay attention to the creative designs of the authors as well. That unveiled another, no less important truth to me. The artists who had their works exhibited in the museum not only offered the beauty of the art pieces to the viewers, but also granted some ideas to their peers. No swanky blacksmithing magazine would match to the impression from the live observation of an artwork. All the meetings with the blacksmiths from different regions, discussions on general issues, and conferences were positive and necessary components for the overall development of Ukrainian blacksmithing" [9].

Since 2014, the powerful blacksmithing festival in Donetsk ceased it operation and no longer is a trendsetting national cultural project. Active warfare and occupation broke the connections with the blacksmiths in Donetsk. During the recent years, the Park of Forged Figures has changed dramatically. However, it still is a favorite walking destination for Donetsk dwellers. "August of 2014 comes to my mind. Donetsk is deserted, all people are gone, but we decided to go on with the festival nevertheless. Only five blacksmiths consented to join and we came to the square and started working. People who attended the festival were crying and thanked us, as something positive was still going on in the city" [8].

Conclusions. The study analyzes the processes of development and functioning of the Park of Forged Figures as the culture-generating space, which reflects 
main professional, artistic, stylistic, and general theoretical issues of contemporary Ukrainian blacksmithing art. The points to be emphasized are:

- the main artistic and style features of the majority of artworks in the Park of Forged Figures are experiments with the individual style, the most distinct of which were hi-tech, ethnic styles and modernism,

- combination of various genre, style, technological trends of blacksmithing art in one exhibition space of blacksmithing culture makes the Park of Forged Figures a unique phenomenon of blacksmithing culture and reflects general tendencies in development of this art,

- the phenomenon of creation of a polystilistic artwork was researched,

- collaboration contributes to cultural unification of blacksmithing community, improves professional skills, promotes blacksmithing art in Ukraine, - works of blacksmithing art produced by various
Ukrainian schools and trends, presented in the Park of Forged Figures, not only formed a common exhibition space but also founded the museum space for Ukrainian blacksmithing art where development of Ukrainian blacksmithing of the early $21^{\text {st }}$ century could be traced.

All wars come to their end. The current bloody war, with Ukrainian soldiers, volunteers, and civilians dying, will also end one day. The East of Ukraine will be in peace again. Therefore, cultural policy would be a powerful instrument of mutual understanding. The Park of Forged Figures, founded by the blacksmiths from nearly all regions of Ukraine, would play an important role in national reconciliation and in the start of a new peaceful life. Thus, blacksmithing would be not only cultural but also a social factor contributing to finding realistic ways of peaceful settlement of extremely complex and complicated life challenges.

\section{References}

1. Afanasiev, A. (2008) Slavyanskaya mifologiya. Moscow: Eksmo; Sankt-Peterburg: Midgard.

2. Bonkovska, S. (1991) Kovalstvo na Ukraini (XIX-pochatok XX st.), ed. V. Zakharchuk-Chuhai. Kyiv: Naukova dumka.

3. Borschenko, L. (2006) 'Khudozhnie lytvo na staromu luhanskomu zavodi (1795-1887)', MIST (mystetstvo, istoriia, suchasnist, teoriia: zb. nauk. pr. z mystetstvoznavstva $i$ kulturolohii), vol. 3, pp. 22-28.

4. Burduk, V., Rohotchenko, and O., Rudenko, I. (2007) Khudozhnie kovalstvo Ukrainy, vol. 1: Vidrodzhennia. Donetsk: Rehion.

5. Voitovych, V. (2005) Ukrainska mifolohiia, 2nd ed. Kyiv: Lybid, $664 \mathrm{~s}$.

6. Volodin, G. (1967) 'Mertsalovskaya palma' in Po sledam istorii. Ocherki iz istorii Donetskogo ordena Lenina metallurgicheskogo zavoda imeni V. I. Lenina. Donetsk: Donbass, pp. 38-43.

7. Zholtovkyi, P. (1972) Khudozhnii metal. Istorychnyi narys. Kyiv: Mystetstvo.

8. Interview with V. Burduk by S. Rohotchenko. 11 November, 2017. Kyiv.

9. Interview with O. Yurchenk by S. Rohotchenko. 19 July, 2020. Kyiv.

10. Kotsarenko, V. (2000) 'Palma Mertsalova - symvol Donbassa', Tekhnopolys, vol. 7 (396), 17 February.

11. Lototska, V. (2016) 'Sakralnist motyviv roslynnoho svitu v ukrainskomu plastychnomu mystetstvi', Narodoznavchi zoshyty, vol. 6 (132), pp. 1423-1427.

12. Loshadkin, I. (2005) 'Kolonka glavnogo redaktora', Zhurnal o metalle, vol. 1(5), p. 3.

13. Mohylevskyi, V. (1990) Hudozhestvennyiy metall v arhitekture Kieva seredinyi XVII-nachala XX st.

[Ph.D. thesis abstract, Moscow State Stroganov Academy of Industrial and Applied Arts.]

14. Park kovanykh skulptur u Donetsku. (n. d.) [online]. Available at: https://ua.igotoworld.com/ua/poi_ object/66086_forged-figures-park-in-donetsk.htm (accessed: 20 November, 2017). 
15. Popiuk, I. (2007) 'Tvorchist suchasnykh bukovynskykh maistriv khudozhnoi obrobky metalu v konteksti yevropeiskoho mystetskoho protsesu', Ukrainske mystetstvoznavstvo: materialy, doslidzhennia, retsenzii, vol. 7, pp. 88-91.

16. Poshyvailo, I. Symvolizm narodnoi kultury ukraintsiv: derevo zhyttia (2010) [online]. Available at: https:// honchar.org.ua/p/symvolizm-narodnoji-kultury-ukrajintsiv-derevo-zhyttya/ (Accessed: 10 July 2020).

17. Pro Ukrainu (n. d.) [online]. Available at: http://about-ukraine.com/gorschik-abo-glechik/\#: :text (Accessed: 10 July 2020).

18. Reklamnyi prospekt kovalskoho pidpryiemstva "Gefest" (1999) Donetsk: [n. p.].

19. Rudenko, I. (2006) 'Khudozhestvennaya kovka', MIST (mistetstvo, IstorIya, suchasnIst, teorIya: zb. nauk. pr. $z$ mistetstvoznavstva $i$ kulturologiyi), vol. 3, pp. 298-307.

20. Kysliak, V. and Neskoromnyi, A. (eds.) (2010) Ukraina: herby ta prapory. Kyiv: Parlamentske vydavnytstvo.

21. Shmahalo, R. (2015) Entsyklopediia khudozhnoho metalu, vol. 1: Svitovyi ta ukrainskyi khudozhnii metal. Klasyfikatsiia, terminolohiia, stylistyka, ekspertyza. Lviv: Apriori.

22. Yaseniv, Ye. (2009) Prohulianky po Donetsku. Donetsk: Vydavnytstvo Horbasova I. O.

\section{$\Lambda$ ітература}

1. Афанасьєв А. Н. Славянская мифология. Моска: Эксмо; Санкт-Петербург: МиАгарА, 2008.1520 с.

2. Боньковська С. М. Ковацьство на Україні (XIX - початок XX ст.) / віАп. реА. В. В. Захарчук-Чугай; НАН України; ІМФЕ ім. М. Т. Рицьського. Аьвівське відАілення. Київ: Наукова Аумка, 1991. 112 с.

3. Борщенко $\Lambda$. Художнє Аитво на старому муганському заводі (1795-1887) // МІСТ (мистецтво, історія, сучасність, теорія: зб. наук. пр. з мистецтвознавства і культурології). 2006. № 3. С. 22-28.

4. Бураук В., Роготченко О., Руденко І. Художнє ковальство України. Аонецьк: Регіон. 2007. Кн. 1: ВіАродження. 120 с.

5. Войтович В. М. Українська міфологія. ВиА. 2-ге, стереотип. Київ: Аибідь, 2005. 664 с.

6. Володин Г. Мерцаловская пальма // По следам истории. Очерки из истории Аонецкого ордена

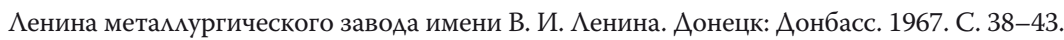

7. Жолтовський П. Художній метал. Історичний нарис. Київ: Мистецтво, 1972. 113 с.

8. Інтерв'ю С. Роготченко з В. Бурауком. 11.11.2017. Київ.

9. Інтерв'ю С. Роготченко з О. Юрченком. 19.07.2020. Київ.

10. Коцаренко В. Пальма Мерцалова - симвоц Аонбасса // Технополис. 17 февраля 2000. № 7 (396).

11. Аотоцька В. Сакральність мотивів рослинного світу в українському пластичному мистецтві // Народознавчі зошити. 2016. № 6 (132). С. 1423-1427.

12. АошаАкин I. Колонка главного редактора // Журнац о металме. 2005. № 1(5). С. 3.

13. Могилевский В. Ю. Художественный метам в архитектуре Киева середины XVII - начала XX ст.: автореф. Аисс. ... канА. искусствоведения. Москва, 1990. 21 с.

14. Парк кованих скульптур у Аонецьку. URL: https://ua.igotoworld.com/ua/poi_object/66086_forgedfigures-park-in-donetsk.htm (Аата звернення: 20.11.2017).

15. Поп'юк І. Творчість сучасних буковинських майстрів художньої обробки металу в контексті європейського мистецького процесу // Українське мистецтвознавство: матеріали, АосліАження, рецензії. 36. наук. праць / голов. реА. Г. Скрипник; НАН України, ІМФЕ ім. М. Т. Рильського. Київ, 2007. Вип. 7. С. 88-91.

16. Пошивайло I. Символізм народної культури українців: Аерево життя. URL: https://honchar.org.ua/p/ symvolizm-narodnoji-kultury-ukrajintsiv-derevo-zhyttya/ (Аата звернення: 07.10.2020) 
17. Про Україну. URL: http://about-ukraine.com/gorschik-abo-glechik/\#: :text (Аата звернення: 07.10.2020).

18. Рекцамний проспект ковальського піАприємства «Гефест». Аонецьк, 1999. 4 с.

19. Руденко И. Художественная ковка // МІСТ (мистецтво, історія, сучасність, теорія: зб. наук. пр. 3 мистецтвознавства і культурології). 2006. № 3. С. 298-307.

20. Україна: герби та прапори / авт. проекту та упор.: В. Г. Кисляк, О. А. Нескоромний. Київ:

Парламентське виА-во. 2010. 456 с.

21. Шмагало Р. Т. Енцикмопедія художнього металу: у 3 т. Аьвів: Апріорі, 2015. 420 с. Т. 1: Світовий та український художній метац. Класифікація, термінологія, стилістика, експертиза.

22. Ясенів Є. Прогулянки по Аонецьку. Аонецьк: ВиА. Горбасьова І. О., 2009. 256 с.

\section{Роготиенко С. В. «Парк кованих фігур" як художня практика украӥнського ковахьства}

Анотація. «Парк кованих фігур» у Аонецьку є унікальним мистецьким, соціокультурним, політичним, художнім явищем. Як виставковий простір сучасного ковальського мистецтва, він не має аналогів як в Україні, так і за їі межами. Зведений силами ковальської громади України, цей творчий, а згодом і музейний простір за своїми розмірами і кількістю репрезентованих творів й дотепер залишається чи не чисельнішим з точки зору представлених у ньому композицій.

Упродовж 2001-2013 «Парк кованих фігур» був місцем щорічної зустрічі ковалів усіх регіонів України та Світу як унікальний майданчик, де відбувалися майстер класи ковальського ремесла, спеціалізовані конференції, а також і неформальні зустрічі, що активізували передовсім професійні пошуки у цьому виАі творчості. Поряд зі щорічним форумом в Івано-Франківську «Орнаментальне ковальство», донецький «Парк» за ці роки став унікальним місцем експонування художніх пошуків і ковальських практик, експериментів у царині виражальності та стильового розмаїття пропонованих концепцій. Відтак концепційна наснаженість проектів «Парку», розгляА цього явища як знакового у соціокультурному поступі Аержави на підставі проектів, преАставцених регіональними ковацьськими осередками скцадає актуальність цієї статті.

Ключові слова: ковальство, парк кованих фігур, художній метал, полістилізм, фестиваль.

\section{Роготченко С. В. «Парк кованых фигур» как художественная практика украинского кузнечества}

Аннотация. «Парк кованых фигур» в Аонецке является уникальным творческим, социокультурным, политическим, художественным явлением. Как выставочное пространство современного кузнечного искусства, он не имеет аналогов как в Украине, так и за ее пределами. Созданное силами кузнецов Украины, это творческое, а впоследствии и музейное пространство по своим размерам и количеству преАставленных произведений Ао сих пор остается одним из самых многочисленных с точки зрения представленных в нем композиций.

В течение 2001-2013 годов «Парк кованых фигур» был местом ежегодной встречи кузнецов всех регионов Украины и мира, уникальной площадкой, где происходили мастер-кмассы кузнечного ремесла, специализированные конференции, а также и неформальные встречи, которые активизировали прежде всего профессиональные поиски в этом виде творчества. Наряду с ежегодным форумом в Ивано-Франковске «Орнаментальнэ ковальство», Аонецкий «Парк» за эти годы стал уникальным местом экспонирования, художественных поисков и кузнечных практик, экспериментов в области образной выразительности и стилевого разнообразия преАлагаемых концепций. Поэтому концептуальная насыщенность проектов «Парка», рассмотрение этого явления как знакового в социокультурном развитии государства на основании проектов, преАставленных региональными кузнечными центрами, составцяет актуацьность этой статьи.

«Парк кованых фигур» - это музей современного кузнечного искусства, не имеющий аналогов ни в Украине, ни в Европе. Автор рассматривает «Парк кованых фигур» не только как уникальную выставку достижений украинских кузнецов, но и исслеАует участие киевских художников-кузнецов в социокумьтурном проекте государства.

Ключевые слова: ковка, парк кованых фигур, художественный металм, полистилизм, фестиваль. 